\title{
Cain and Abel: Violence, Shame and Jealousy
}

\author{
Rein Nauta
}

Published online: 8 August 2008

(C) The Author(s) 2008

\begin{abstract}
In discussing the murder of Abel by his brother Cain the dynamics of shame and guilt are explored. An analysis of the psychological drama, more than the brutal fact itself, may help to understand the consequences of negation and love for the contemporary occurrences of family violence. In exploring the separate positions of Cain and Abel the differential effects and consequences of jealousy and envy are analyzed as well.
\end{abstract}

Keywords Violence $\cdot$ Guilt $\cdot$ Shame $\cdot$ Jealousy $\cdot$ Envy $\cdot$ Narcissism

Family violence has no meaning. It serves no useful purpose, but is merely an ambiguous expression of impotence and dominance. Random, meaningless acts of violence ignore the individuality of the victim: anyone might be its target. Random acts of violence are antisocial. The apparent powerlessness to avoid or combat the danger of such violence makes modern life threatening and uncertain. That the occurrence of random violence is a sign of our times but nonetheless incomprehensible is what many people most deplore. Its randomness, its total lack of reason, is depressing and generates fear.

\section{Cain}

When searching for an explanation for gratuitous violence, it may be worthwhile to examine more closely the event that may be regarded as prototypical of this phenomenon: the murderous encounter of Cain and Abel. One of the early chapters of Genesis (4.1-8) recounts the story of the birth of Eve's children. As men with responsibilities, farming the land and breeding cattle, they each bring an offering to God, their creator and protector. Yet when they offer their thanks, the counterfactual expression of Man's neediness and impotence after being driven out of Paradise, things go badly. The dynamics of meaningless

R. Nauta (ه)

Department of Religious Studies and Theology, University of Tilburg, P.O. Box 90153 ,

5000 LE Tilburg, The Netherlands

e-mail: R.Nauta@uvt.nl 
violence can be investigated via the drama that consequently unfolds (Bastian and Hilgers 1990). The plot is set into motion when Cain's offering of the fruits of the field is rejected while his younger brother Abel's offering, the fat portion of the season's first calf, is accepted. The rejection and acceptance are random, without reason or meaning, they make no sense. The text, at any rate, provides no explanation. While confirmation and recognition are sought and expected, when gratitude and dependency are expressed, the rejection is absolute, total, and devoid of compromise. The New Revised Standard Version translates: "And the Lord had regard for Abel and his offering, but for Cain and his offering he had no regard. So Cain was very angry, and his countenance fell" (Genesis 4.5). The New Dutch Bible translation gives Cain's reaction to this unexpected and random rejection as one of fury and anger: "Cain then became furious and his countenance darkened." His anger appears to be a sign of envy. Envy makes one feel inferior; a feeling that vanishes when one robs from another what one craves for oneself. The Jewish philosopher Martin Buber (Genesis 4.5; Buber 1987, 17f.) translated this passage differently: "Er achtete auf Habel und seine Spende, auf Kajin und seine Spende achtete er nicht. Das entflamte Kajin und sein Antlietz fiel." And in the Einheitsuebersetzung of 1979 this passage is translated as: “...Da ueberlief es Kain ganz Heisz und sein Blick senkte sich.” Cain's offering is refused, he reddens with shame. His face falls. He has been unexpectedly abandoned by the One he depends on as a farmer and whose good favor he sought. The humiliation and hurt cannot be hidden or repressed, for Abel saw everything.

\section{Guilt and shame}

Shame is the narcissistic affect par excellence. All at once, one's self-image and the image one wants others to believe in is proven false. Such shame cannot be managed or controlled. That is how it differs from guilt. Guilt presupposes freedom: a choice between what should be done and what has been done, between duty and desire, between good and evil. Guilt is the correlate of a free decision that turns out to be wrong. Guilt is related to actions, to what one does. Shame, however, is linked with vision and perception, with selfunderstanding and self-presentation, with the whole of one's existence. Shame is related to the feeling of being wrong. Developmental psychology sees shame and doubt as part of that early stage of life in which children attempt to confirm their autonomy, when to the amusement of their loving, doting parents they try to stand alone and instead demonstrate their impotence by falling down. When the child has made a fool of itself, little is left of a still uncertain self-esteem. Shame results when one fails to achieve one's ego-ideal and is forced to accept one's own inferiority, in particular so when a personal faux pas, perhaps innocent in itself, has been noticed by somebody else.

Guilt always concerns the violation of rules designed to protect the common good. These rules are necessary as a social guarantee and a safeguard of order. Guilt is also part of a later phase of childhood development which manifests itself when the child, in the pursuit of its own interests, does not consider the common good and the rights of others in the collective welfare.

When one is overwhelmed by shame, guilt seems the lesser of two evils. After all, guilt assumes some level of control over a situation that made one powerless and ineffectual. Guilt as the result of bad choices and wrong actions is always limited and finite, while shame is total and all encompassing. Because shame engulfs the entire person, people generally prefer the partiality of guilt, as did Cain. In order to survive, to avoid drowning in self-depreciation and to escape the sudden futility of existence, Cain killed his brother. For 
it was Abel's glance that determined the inescapability of Cain's worthlessness. The killing of Abel does indeed appear to be an example of meaningless violence, although to Cain it was an attempt to come to grips with a situation in which he felt lost and the world appeared to be without meaning. Cain would rather be actively guilty than passively ashamed. Guilt reduces the universal to the partial; guilt implies punishment and possibly forgiveness; guilt can make life better. Felix culpa. Thank God for guilt.

\section{Courage and bravado}

Whilst recognizing the complexity of concrete events, this transformation of shame into guilt may still contribute to a better understanding of meaningless violence. In order to accomplish this, we must consider what human vulnerability means today and how we deal with it. The idea that modern man can be vulnerable and weak seems to contradict the direct but naïve and superficial experience of everyday life. After all, in a modern, individualistic society, life appears to be determined by a plentitude of options and choices. More than ever before, we are able to design our lives according to our personal preferences. We are able to live our lives as we want. But in such a pleasant existence, there is no failure, no setback, which can be easily blamed on government negligence, the dereliction of duty by social institutions, or on failing political systems, etc. There is only our own individual responsibility. Inevitably we fail. We are forced to accept that we are not the all-powerful person aspire to be. Reality does not conform with the conditions laid down by our ego-ideal.

In an age in which individual arrogance and megalomania are socially reinforced, narcissistic vulnerability is high (Capps 1993). Where success is the norm, every failure is that much more painful. Showing such vulnerability is simply not done, however. One should be energetic, not whine, and pretend that everything is OK. Accordingly, in an attempt to defeat their innermost fear of failure, people learn to repress whatever frightens them. Simple office workers feel like heroes when they emerge unscathed from a survival trip in the Ardennes at the boss's invitation; their sense of community is strengthened when, on the advice of a business consultant, they conquer the wilderness together. People feel empowered and validated by bungee jumping off a bridge, climbing a mountain, going on safari, or exploring strange cultures on a travel agent's itinerary. Although billed as a manifestation of freedom and self-confidence, the frequency and extravagant quality of such activities, their peculiar and dramatic implementation, indicates rather that they are expressions of hidden depletion and a search for meaning that cannot be acknowledged to others. It is a fear of being recognized as fragile and fragmented, which as much as possible is hidden from the public eye by the choice of the all too extreme. Notwithstanding appearances to the contrary, it is precisely because of the multitude of opportunities for selfdevelopment and self-realization-and the implied pressure such possibilities exert with respect to performance and distinction - that modern man is particularly vulnerable to failure. At the same time, our culture demands that fear of failure be hidden behind a facade of courage and bravado. Not to be respected when support and admiration are essential, to be laughed at when one fails are fatal injuries to a fragile existence. The shame this generates finds expression in and is, at the same time, hidden by a violent rage. When selfrespect and self-esteem are fatally wounded, concern for others is of no consequence, for the only way to re-affirm one's own victimized self is by destroying those who were witness to its demise. This kind of targeted destructiveness liberates the perpetrator from the dependence and despondency of the shaming experience. The effect of this action is chiefly the acclamation of rediscovered freedom that implies, of course, guilt: the possibility or 
even certainty of the wrong choice. The extremity of violence, the excessiveness of the transgression, and the emphatic guilt are essential since they are persuasive evidence of something regained: control, freedom, self-esteem.

\section{Abel}

The transformation of shame into guilt is also pleasant for bystanders and onlookers. The situation is simple, reduced of complexity: an easy division is made between good and evil, them and us. This kind of dichotomy helps to restore order, make the world safe again, uphold the rules. A maneuver such as this, designed as it is to localize evil, requires some celebration because it proclaims one's innocence publicly in a silent protest that requires recognition and confirmation. Marches are held, flags are flown, their color white, the murderer black. In this perhaps all too emphatic and facile exclamation of their own righteousness, the public plays the role of murdered innocence and all too gladly identifies with the other-good-brother, Abel.

The story of Cain and Abel is about two brothers. Their offerings are not just a sign of gratitude but also a request for the recognition and confirmation needed to live in a threatening world ruled by doubt and uncertainty. In a world such as theirs, gods must be propitiated. To learn that one brother is accepted and preferred, and that the other is disregarded and rejected in what appeared to be a peaceful offering out of simple thankfulness but turned out to be a struggle for love and confirmation, is disturbing and threatening. To be able to live with such ambiguity and uncertainty the rejected brother's very ignobility must be made strikingly and painfully clear by the other's apparent innocence. However, despite appearances, there are no innocents in the arena of love and rejection, of fear and acceptance. Abel is not innocent, for his very existence determines the conflict. Abel is Cain's brother, and none of his brother's desires are alien to him. Abel is just like Cain, only more successful (Drewermann 1989). Yet in order to be successful, he must clearly do his best to remain silent about the competition in which they are locked and refrain from speaking about the victory so gained.

This paradox of a victory won by denying the competition, might all too easily be recognized wherever there is a silent protest against meaningless violence. Notwithstanding the silence, this kind of protest is a resounding proclamation of the moral superiority of Abel, and all those peaceful, grateful people like him, to the perpetrators of that horrible crime. Celebrating silence as a reaction to meaningless, random violence may also be understood as a dubious attempt to repay guilt with shame. The exemplary meaning of a silent protest is akin to that of the depressive blackmail to correct the wrongdoings of a wayward child, which is imposed by a mother who is not angry but sad. What is tragic about this kind of protest, however, is that it presumes that the dilemma is irreconcilable. An ontological deficit - the culprit is worthless - is put in the place of failing pragmatics: the culprit just did something wrong.

\section{Jealousy and envy}

The story of Cain and Abel demonstrates that there are no innocents. Every Abel needs his Cain in the struggle for recognition and admiration if he is to take pride in himself. Likewise, every Cain is aroused to anger by envy of the silent pageantry of the sanctimonious, self-effacing brother called Abel. 
Yet perhaps it was not envy but jealousy that consumed Cain. Cain was rejected even though he loved God. Being rejected without reason by someone you love, someone you wanted to and thought you could trust is perhaps the worst thing that can happen to a person. Cain experiences the rejection of his offering as a traitorous act. God commits adultery (Berke 1986). Cain's love implied that love is to be exclusive. But it turns out there are others who share in God's love, and are even loved more, who are preferred. Then the world comes crashing down. Disappointment in the former love object is transformed into hatred of the intruder who stole the love to which one believed oneself solely entitled. Incomprehension feeds a raging jealousy. A jealousy driven by love and the desire to be loved is radically different from envy. The distinctive nature of this jealousy is determined by the triadic character of the relations in question. Jealousy ensues when love's monopoly is broken, a love based on the simple promises: I love you and you love me. When the reciprocity of love turns out to be an illusion, when one must believe that one's love has been stolen by somebody else, then revenge must be taken.

Jealousy, stemming from lost love, should be distinguished from vulgar envy. Jealousy expresses disappointment at what was incorrectly understood to be a reciprocal relationship. Thus disappointed, but still in love, one blames a third party for having stolen one's love. Envy, however, knows nothing of altruistic love, but is fascinated by monomaniacal selflove. Envy is dyadic. In envy, one is envious of what another, in one's eyes unjustly, possesses. We may recognize this in the behavior of that mother who says nothing when Solomon proposes chopping the disputed child in half: If I can't have the child, then nobody else will. Cain is not envious, he is jealous. Jealousy can perhaps be understood as a helpless attempt to excuse the one who unexpectedly and suddenly gives his love to somebody else by attributing that dramatic loss to the power of the intruder. Lethal hate for the intruder expresses the continuing love for the original love object. Jealousy desperately tries to secure the love that appears to be lost. Betrayed, rejected, and humiliated, Cain is overwhelmed by hatred for the rival who steals the object of his love. He kills his brother Abel out of jealousy. This appears to be senseless violence, but it is not without meaning.

To protect him from revenge by those who fear an explosion of violence, Cain is marked with a significant sign, a sign warning others not to repay evil with evil. While Abel's ostensibly senseless murder seems to threaten the foundations of civil society, Cain's mark is an act of consequence. It shows Cain's vulnerability and returns, as a blessing in disguise, the love he thought lost. The murder of Abel, an act stemming from disappointed love, must not be avenged; otherwise a fearful spiral of violence will evolve. The mark protects Cain from those who fail to recognize how disappointed love has led to murder, from those who cannot appreciate the drama in which Cain has forfeited love on account of love. Cain's mark is an expression of compassion for the injured heart at the core of the fratricidal tragedy.

\section{Meaningless violence?}

In order to conclude this analysis of meaningless violence, we must pay some attention to the shame dynamics that determine it. Narcissistic problems occupy a prominent position in contemporary culture (Mooy 1998). They relate to the instability of self-esteem that (without a clear cause) fluctuates between feelings of utter worthlessness and grandiose magnificence. This problem is exemplary exposed in the excessive concern of so many ordinary men and women about their public image and in their uncertainty as to whether that image is sufficiently appreciated. Acts of violence are affronts to self-esteem, affronts 
whose severity is experienced in direct proportion to the grandiosity of the originally imagined value of the self. The paradox in the dynamics of violence is that the judgments of others weigh so heavily because they reflect our repressed and hidden self-knowledge. This is why shattering the illusion of assumed omnipotence and invulnerability leads to horrific consequences (Mooy 1998). It is precisely homicide and murder, that is the taking of another's life in reaction to being injured, which confirm in extremis the perceived threat to omnipotence and greatness.

If violent behavior can be regarded as a reaction and defense against shame, the sociopolitical consequences of institutional disrespect and public disgrace are also relevant to our analysis. As long as government bureaucracies continue to believe that they always know better than the average citizen, as long as big business continues to prefer interchangeability and replaceability to loyalty, as long as collegiality (at universities, for example) continues to be sacrificed to hierarchy, and performance to production, the effect of such policies and strategies are experienced as willful attacks on the self-esteem of ordinary citizens, clients, customers, and employees. Such offences imply a repudiation of the façade behind which one tries to keep alive the pretence of a successful life. The individual must conclude that, in the eyes of those who are set above him, his value is nil and hence of no consequence. In a society in which nobody counts, every such narcissistic injury generates great anger. Violence in all its forms matches the pressure to present oneself as competent, successful, accepted, as someone of worth whose self-esteem is validated. This kind of violence is not only physical. Everyday crudity, vulgarity, and arrogance are expressions of the shameful and violent defense against attacks on a vulnerable self. Shame is felt even more strongly when dealing with matters of intimacy. This accounts, in part, for sexual violence. Pornography, rape, domestic violence are no less narcissistic attempts to restore self-esteem by humiliating another (Stoller 1987). The express repudiation of social, cultural, or sexual taboos in general should be seen as an exercise in narcissistic repair by shaming the naïve and innocent. Road rage, traffic aggression, modern architecture's unsightliness, and conspicuous consumption should all likewise be understood as expressions of hate and vengefulness full of shame and stemming from feelings of inferiority and disappointment. Such violence, though unpleasant, is not meaningless. It has a purpose, although perhaps it suits us better to close our eyes to the dark side of our own existence. To cultivate the concept of meaningless, senseless violence is a final attempt to maintain the idea of a just world supporting the pretence of our own innocence.

\section{Hope and humor}

How to survive that sense of inferiority and shame reflected in the depreciating smile of all those who perceive and value the poor performance apparently given by us in life's theatre? That life support must be derived from the trust and hope we should have learned while we were fed and weaned as infants. Cherishing the hope that is in us, we might be able to conquer our vulnerability and follow our own path with equanimity, believing that some day we will be seen as we are. That inner conviction must be achieved in childhood, when, in the relations with the most important people in our life, it is not injury that was predominant, but support and confirmation (Erikson 1964). Hope is learned when one can count on a mother's constant care and lasting providence. It is the primary identification with one's mother, experienced as an extension of the self, that made and makes the finite nature of one's own existence acceptable. At the same time, a narcissistic vulnerability, for which hope of a better life to come is the sole panacea, is the result of an indifferent or 
distrustful pedagogy characterized by parental negligence or over-indulgence. To keep hope alive, some desires must be abandoned and traded in for a more realistic vision of the future. Hope requires continual adaptation to the possibilities of the moment (Pruyser 1963). Both the abandonment of desires and the continuous creation of new, more feasible aspirations are thus needed to counterbalance the temptation to surrender to delusory dreams (cf. Capps 1995). Hope and shame, mutually exclusive, keep each other in a painful equilibrium, to be upset in favor of hope via a trained capacity for appreciating the absurd.

In the end, humor helps best to conquer the tyranny of the narcissistic self (Kohut 1966). A sense of humor and a conception of the finite and transient nature of life ensure that illusions can be relinquished without any lapse into sarcasm or cynicism. Only when freed of illusions is it once again possible to believe in the power of the ego-ideal, of any ideal. This position, in which one views and accepts with light irony both the minor and major importance of one's own existence, forms the final barrier against the loss of the self.

Open Access This article is distributed under the terms of the Creative Commons Attribution Noncommercial License which permits any noncommercial use, distribution, and reproduction in any medium, provided the original author(s) and source are credited.

\section{References}

Bastian, T., \& Hilgers, M. (1990). Kain. Die Trennung von Scham und Schuld am Beispeil der Genesis. Psyche, 44, 1100-1112.

Berke, J. H. (1986). Shame and envy. British Journal of Psychotherapy, 2, 262-270.

Buber, M. (1987). Die fünf Bücher der Weisung. Heidelberg: Schneider.

Capps, D. (1993). The depleted self. Sin in a narcissistic age. Minneapolis: Fortress.

Capps, D. (1995). Agents of hope, a pastoral psychology. Minneapolis: Fortress.

Drewermann, E. (1989). Kleriker. Psychogramm eines Ideals. Olten und Freiburg im Breisgau: Walter-Verlag.

Erikson, E. H. (1964). Insight and responsibility. New York: Norton.

Kohut, H. (1966). Formen und Umformungen des Narzissmus. Psyche, 8, 561-587.

Mooy, A. (1998). Psychiatrie, recht en de menselijke maat. Over verantwoordelijkheid. Amsterdam/Meppel: Boom.

Pruyser, P. W. (1963). Phenomenology and dynamics of hoping. Journal for the Scientific Study of Religion, 3, 86-96.

Stoller, R. J. (1987). Pornography: Daydreams to cure humiliation. In D. L. Nathanson (Ed.), The many faces of shame (pp. 292-307). New York/London: Guildford. 